\title{
PENGARUH DINAMIKA INTERNAL PARTAI TERHADAP STRATEGI POLITIK PARTAI AMANAT NASIONAL PASCA KONGRES IV TAHUN 2015
}

\author{
Ratnia Solihah \\ Departemen Ilmu Politik FISIP UNPAD \\ E-mail: ratnia@unpad.ac.id
}

\begin{abstract}
ABSTRAK
Konflik internal di dalam partai politik umumnya terjadi di lembaga-lembaga politik, terutama dalam konteks berjuang untuk kekuasaan atau kepemimpinan dalam partai politik. Tapi konflik internal dalam proses pemilu saat ini Ketua IV kongres Partai Amanat Nasional (PAN) di Bali pada tahun 2015 tidak menimbulkan konflik berkepanjangan sampai dualisme kepemimpinan partai atau calon ketua yang kalah dalam persaingan politik dengan mendirikan sebuah partai politik baru. Pasca pemilihan Ketua PAN Zulkifli Hasan menggantikan Hatta Rajasa. menimbulkan dinamika politik internal baru telah terjadi di partai itu, yang juga memengaruhi perubahan strategi politik untuk maupun eksternal PAN, yang bertujuan untuk meningkatkan kemampuan partai, kepercayaan publik/masyarakat terhadap PAN dan untuk meningkatkan PAN elektabilitas dalam pemilu tahun 2019.
\end{abstract}

Kata kunci: dinamika internal, partai politik, strategi politik

\section{THE IMPACT OF INTERNAL PARTY DYNAMICS TO THE STRATEGY OF NATIONAL MANDATORY PARTY (PAN) AFTER THE 4TH CONGRESS IN 2015}

\begin{abstract}
Internal conflicts within a political party common place in political institutions, especially in the context of fighting for power or leadership in a party. But internal conflicts in the electoral process currently Chairman of the PAN congressional IV in Bali in 2015 does not lead to a prolonged conflict until the dualism of leadership of a party or departure of chairman candidate who lost in the political competition by setting up a new political party. Post-election of Chairman of the National Mandate Party Zulkifli Hasan replacing Hatta Rajasa. raises the political dynamics of internal new has happened in the PAN, which also affect changes in political strategy PAN good political strategy for the internal PAN and external PAN, which aims to increase the capabilities of the party, the public trust/society against the PAN and to improve elektabilitas PAN in elections in 2019.
\end{abstract}

Key words: internal dynamics, political parties, political strategy

\section{PENDAHULUAN}

Partai Politik adalah salah satu komponen atau aspek yang menempati kedudukan yang sangat penting dalam kehidupan suatu negara. Baik buruknya sistem politik suatu negara sangat dipengaruhi dan ditentukan oleh berbagai dinamika partai politik yang ada dalam negara tersebut. Dinamika suatu partai politik, baik dinamika internal maupun dinamika eksternal menentukan strategi dan peran politik yang dilakukan oleh partai politik dalam sistem politik.
Berbagai permasalahan politik salah satunya dapat diamati dari aspek dinamika internal partai politik, yang menyebabkan kinerja partai politik sebagai salah satu institusi politik yang ada dalam lembaga legislatif terganggu. Beberapa konflik internal partai politik menyebabkan partai politik secara institusional tidak mampu berperan maksimal dalam menjalankan tugas dan fungsinya yang berimbas pada peran dan fungsinya sebagai lembaga perwakilan rakyat yang seharusnya lebih mengedepankan kepentingan masyarakat daripada kepentingan kelompok atau partainya. 
Kondisi ini dapat menyebabkan berkurangnya kepercayaan masyarakat terhadap partai politik tersebut.

Namun di sisi lain adanya dinamika internal partai politik juga dapat menyebabkan munculnya strategi politik partai politik yang berhasil meningkatkan kinerja partai menjadi lebih baik dan berperan dalam mempengaruhi kepercayaan publik terhadap partai tersebut.

Salah satu partai yang mengalami dinamika internal adalah Partai Amanat Nasional (PAN). Pada Tahun 2015, PAN telah menyelenggarakan kongres Nasional ke IV yang dilakukan di Bali untuk menentukan dan memilih Ketua Umum yang baru. Dalam kongres tersebut, terjadi perbedaan pendapat dari pendukung kedua calon yang juga menghasilkan dua kubu dalam internal PAN tersebut, yaitu kubu yang mendukung Hatta Rajasa untuk kembali menjadi Ketua Umum PAN, dan kubu Zulkifli Hasan yang dipelopori Amien Rais. Namun publik seakanakan tidak merasakan adanya konflik internal yang terjadi dalam partai tersebut, bahkan PAN mampu melakukan strategi politiknya untuk tetap berperan dalam kancah politik nasional.

Hal inilah yang menjadi ketertarikan penulis untuk melakukan kajian tentang dinamika internal partai politik yang tidak meng-arah kepada konflik tetapi lebih mengarah kepada strategi politik yang dilakukan oleh institusi partai untuk lebih mengedepankan kepentingan institusi partai dari pada kepentingan orang perorang atau kepentingan kelompok, sehingga secara intitusional PAN tetap mendapat kepercayaan dari konstituen dan pendukung internalnya. Berdasarkan hal tersebut, dalam tulisan ini penulis akan membahas tentang Pengaruh Dinamika Internal Partai terhadap Strategi Politik PAN Pasca Kongres PAN ke-IV Tahun 2015.

\section{TINJAUAN PUSTAKA}

Partai politik merupakan salah satu dari bentuk pelembagaan sebagai wujud ekspresi ide-ide, pikiran-pikiran, pandangan, dan keyakinan bebas dalam masyarakat demokratis. Di samping faktor-faktor yang lain seperti pers yang bebas, peranan kelas menengah yang tercerahkan, tersedianya ruang publik bagi masyarat, dan sebagainya, peranan partai politik dapat dikatakan sangatmenentukan dalam dinamika kegiatan bernegara. Pertai politik sangat berperan dalam proses dinamis perjuangan nilai dan kepentingan (values and interests) dari konstituen yang diwakilinya untuk menentukan kebijakan dalam konteks kegiatan bernegara. Partai politik lah yang bertindak sebagai perantara dalam prosesproses pengambilan keputusan bernegara, yang menghubungkan antara warga negara dengan institusi-institusi kenegaraan.

Hal tersebut sebagaimana dikemukakan Miriam Budiardjo, bahwa partai politik merupakan sarana bagi warga negara utuk turut serta atau berpartisipasi dalam proses pengelolaan negara (Budiardjo, 2015: 397). Sigmun Nuewman mengemukakan "Partai Politik adalah organisasi dari aktivitas-aktivitas politik yang berusaha untuk menguasai kekuasaan pemerintahan serta merebut dukungan rakyat melalui persaingan dengan suatu golongan atau golongan-golongan lain yang mempunyai pandangan yang berbeda (A political party is the articulate organization of society's active political agents, those who are concerned with the control of governmental polity power, and who compete for popular support with other group or groups holding divergent views"). (dalam Budiardjo, 2008: 404).

Partai politik adalah kunci penting dalam proses berjalannya demokrasi di suatu negara. Apalagi jika kita menganalisisnya dari sisi filosofis dimana dalam konsep awal lahirnya demokrasi, partai politik merupakan suatu representasi dari suatu tatanan masyarakat yang beradab. Sebuah tatanan dimana segala aspirasi setiap individu tersampaikan dan terakomodir dalam proses perumusan politik.

Begitu pentingnya kedudukan parpol, sehingga sering dikatakan pula, tidak ada demokrasi tanpa kehadiran parpol di dalamnya. Walaupun begitu, perlu digaris bawahi bahwa, pertama, sistem demokrasi hanya bisa bekerja apabila parpol juga bekerja dalam suatu kerangka sistem kepartaian yang mendukung dan memungkinkan demokrasi bekerja. Kedua, tidak semua partai politik bisa memberikan kontribusi positif bagi perkembangan demokrasi. Ketiga, demokrasi tidak semata-mata identik dengan jumlah parpol, seolah-olah semakin banyakjumlah parpolmaka suatunegara semakin demokratis. Di sejumlah negara demokrasi yang telah mapan seperti di Amerika Utara dan Eropa Barat, jumlah parpol yang berkompetisi di tingkat nasional justru semakin berkurang (Haris, 2014: 45) 
Berkaitan dengan pentingnya parpol dalam sistem demokrasi tersebut, keberadaan partai politik dalam sistem politik memiliki beberapa fungsi yang harus dijalankannya sebagaimana dikemukakan dalam UU No. 02 Tahun 2008 pasal 11, bahwa partai politik berfungsi sebagai sarana: (a) pendidikan politik bagi anggota dan masyarakat luas agar menjadi warga negara Indonesia yang sadar akan hak dan kewajibannya dalam kehidupan bermasyarakat, berbangsa dan bernegara; (b) penciptaan iklim kondusif bagi persatuan dan kesatuan bangsa Indonesia untuk kesejahteraan masyarakat; (c) Penyerap, penghimpun dan penyalur aspirasi politik masyarakat dalam merumuskan dan menetapkan kebijakan negara; (d) partisipasi politik warga Negara; dan (e) rekrutmen politik dalam proses pengisian jabatan politik melalui mekanisme demokrasi dengan memperhatikan kesetaraan dan keadilan gender.

Secara Umum, fungsi partai politik dapat dibagi menjadi 7 fungsi, yaitu: sosialisasi politik, partisipasi politik, rekrutmen politik, komunikasi politik, artikulasi kepentingan, agregasi kepentingan dan pembuatan kebijaksanaan (Mas'oed \& McAcdrews, 2008: 79-85). Sedangkan menurut Miriam Budiardjo, fungsi partai politik dapat dibagi menjadi 4 fungsi, yaitu: sarana komunikasi politik, sarana sosialisasi politik, sarana rekrutmen politik dan sarana mengelola konflik (Budiardjo, 2015: 405-409)

Dijalankannya fungsi-fungsi partai politik tersebut akan mempengaruhi peran dan kinerja partai sebagai institusi politik yang berpengaruh pada sistem politik suatu negara. Pelaksanaan fungsi-fungsi partai politik ini juga tidak dapat dilepaskan dari dinamika politik yang ada di luar maupun internal partai politik yang bersangkutan. Oleh karenanya fungsi partai sebagai sarana komunikasi politik dan sebagai sarana mengelola konflik turut menentukan dan mempengaruhi dinamika yang terjadi dalam partai politik tersebut dalam menjalankan aktivitas politiknya.

Dinamika partai politik dapat dilihat sebagai dinamika kelompok yang terjadi dalam konteks dan ranah politik. Menurut Shertzer dan Stone, dinamika kelompok adalah kekuatan-kekuatan yang berinteraksi dalam suatu kelompok pada waktu kelompok melakukan kegiatan-kegiatan untuk mencapai tujuannya (http://www. maribelajarbk.web.id 2015) diakses ada tanggal 18 agustus 2016).
Dinamika politik merupakan kekuatankekuatan individu maupun kelompok yang berinteraksi dalam suatu institusi atau lembaga politik.

Dinamika politik adalah gerak yang mendorong terjadinya perubahan sikap perilaku yang dilakukan secara sengaja yang kemudian memberikan warna dan perubahan pada pemerintahan. Dinamika tersebut muncul karena desakankebutuhan internal dan eksternal partai sebagai kelompok yang terorganisir dan merupakan dampak dari interaksi masyarakat (Jatmiko, 2010: 29).

Adanya dinamika politik menyebabkan suatu institusi politik melakukan terobosanterobosan politik dalam menjalankan aktivitas politiknya. Salah satunya melalui strategi yang dilakukan partai politik, agar dinamika politik yang ada berupa peluang dan ancaman dari lingkungan internal dan eksternalnya dapat dihadapi dan dijadikan sebagai salah satu bentuk kapasitas dan kapabalitas partai politik tersebut dalam mengelola institusinya menjadi lebih baik.

Adanya strategi politik sebagai akibat dari dinamika politik yang terjadi baik dalam internal maupun eksternal partai, antara lain dilakukan melalui dijalankannya beberapa fungsi partai politik, yaitu melalui sarana komunikasi politik maupun dengan sarana mengelola konflik, sehingga adanya dinamika internal maupun eksternal dalam partai politik tersebut tidak menyebabkan kemunduran atau pun berkurangnya kepercayaan konstituen dan publik terhadap partai politik yang bersangkutan. Adanya strategi politik yang dilakukan suatu partai politik sebagai akibat dari dinamika politik bahkan didapat dijadikan sebagai peluang partai politik untuk melakukan kebijakan partai politik yang lebih baik dari sebelumnya dan dapat mengakomodir aspirasi anggota partai politik agar tetap solid dan mendapat kepercayaan politik dari masyarakat.

Strategi politik pada dasarnya masih relatif kurang didefinisikan oleh pakar politik, sehingga terkadang sulit dipisahkan antara pengertian strategi dengan pengertian taktik, karena secara luas pengertian kedua istilah tersebut adalah mengarah pada sebuah seni dalam menggunakan 'kekuatan bersenjata' dalam pertempuran untuk memenangkan peperangan. Pada hakikatnya, strategi dalam komunikasi politik adalah 
keseluruhan keputusan kondisional tentang tindakan yang akan dijalankan saat ini, guna mencapai tujuan politik pada masa depan. Justru itu, merawat ketokohan dan memantapkan kelembagaan politiknya xakan merupakan keputusan strategis yang paling tepat bagi komunikator politik untuk mencapai tujuan politik ke depan, terutama memenangkan pemilihan umum (Arifin, 2011: 235-236).

Dalam Oxford Learner's Pocket Dictionary, strategy is plan indeed achieve a particular purpose atau rencana yang diharapkan untuk meraih sebagian tujuan (Oxford Learner's Pocket Dictionary, English: Oxford Dictionary Press, 2003: 427). Dengan demikian strategi adalah seperangkat aktivitas yang digunakan untuk merencanakan, menentukan dan mengevaluasi berbagai cara untuk mencapai misi dan tujuan yang diharapkan. Strategi adalah suatu alat dan cara untuk mendapatkan sesuatu yang diinginkan. Strategi politik kemudian diartikan sebagai alat politik untuk mendapatkan sesuatu. Baik itu mendapatkan kemenangan, jabatan, dan kekuasaan.

Menurut Peter Schorder, strategi politik merupakan strategi atau teknik yang digunakan untuk mewujudkan suatu cita-cita politik. Strategi politik sangat penting untuk sebuah partai politik, tanpa adanya strategi politik, perubahan jangka panjang sama sekali tidak akan dapat diwujudkan. Perencanaan strategi suatu proses dan perubahan politik merupakan analisis yang gamblang dari keadaan kekuasaan, sebuah gambaran yang jelas mengenai tujuan akhiryang ingin dicapai dan juga segala kekuatan untuk mencapai tujuan tersebut. Peter Schroder menjelaskan bahwa terdapat empat perencanaan strategi, yaitu, i) pendekatan metodologis: kemiliteran, berorientasi pasar, politis, ii) model kemiliteran, iii) model perencanaan korporasi, dan iv) model perencanaan politis (Schroder, 2008: 11-19).

Dalam pendekatan metodologis, terdapat gambaran yang memiliki makna masing-masing ada perbedaan dan persamaan. Pendekatan tersebut saling berpotongan tidak hanya karena dalam persamaan metodologinya, tetapi juga karena beberapa menjadi bagian dari strategi lainnya. Strategi militer dapat selalu menjadi bagian dari strategi politis, dan sebuah strategi politis juga selalu merupakan strategi pasar, atau setidaknya menunjukkan adanya orientasi pasar, yang perlu kita lihat pada saat kampanye pemilu (Schroder, 2008: 13).

Sedangkan dalam proses perencanaan politis terdapat pola yang diutamakan yaitu:

Perencanaan strategi melakukan upaya untuk memposisikan organisasi berdasarkan realita lingkungan operasionalnya. Ada dua jenis lingkungan: i) lingkungan eksternal yang merupakan wilayah dimana kekuatan atau faktor lain mempengaruhi atau dipengaruhi oleh organisasi tersebut. ii) lingkungan internal, yang terdiri atas sumberdaya-sumberdaya, kekuatan, peluang, serta tuntutan dari dalam organisasi itu sendiri. Perencanaan strategi harus mampu mengenali dan menilai peluang dan ancaman yang terjadi di lingkungan eksternal yang berhubungan dengan visi, serta tujuan akhir organisasi (Schroder, 2008: 19).

\section{HASIL DAN PEMBAHASAN}

Pada Tahun 2015, Partai Amanat Nasional (PAN) telah melakukan kongres nasional ke IV yang dilaksanakan di Bali untuk menentukan Ketua Umum Partai yang baru. Dalam kongres tersebut terpilih Hatta Rajasa dan Zulkifli Hasan untuk menjadi calon Ketua Umum PAN. Kedua calon tersebut sama-sama memiliki peluang yang kuat untuk menjadi ketua umum PAN. Persaingan dari kedua calon tersebut bukan hanya menjadi persaingan antar individu, namun persaingan tersebut merambah hingga ke kader partai lain yang hadir dalam kongres tersebut, yang menyebabkan perbedaan pendapat yang terjadi di antara kedua kubu masing-masing pendukung calon ketua umum.

Beberapa media menyebutkan bahwa kongres yang terjadi pada saat itu berjalan dengan panas sehingga menyebabkan kerusuhan atau terjadinya kisruh dalam Kongres PAN yang ke IV tersebut. Perbedaan pendapat yang menyebabkan terpecahya 2 kubu dalam PAN tersebut didasari oleh persepsi dari masingmasing pendukung dari calon ketua umum (http://news.detik.com, 2016) diakses 18 Agustus 2016).

Menurut para pendukung Zulkifli Hasan, beliau pantas untuk menjadi ketua umum PAN untuk kesinambungan pengkaderan. Selain itu, beliau dianggap pantas menjadi Ketua Umum PAN karena memiliki pengalaman politik yang cukup lama untuk memimpin partai. Jenjang 
pengalaman organisasi politik Zulkifli Hasan dianggap suadh sangat lengkap, dimulai dari Ketua Departemen PAN, Sekretaris Jendral PAN, Wakil Ketua Umum PAN, Ketua Fraksi PAN DPR, dan sudah pernah menjadi Menteri. Selain itu pada saat pencalonan sebagai calon Ketua Umum PAN, Zulkifli Hasan sedang menjabat sebagai Ketua MPR-RI periode 2014-2019. Selain alasan itu, ada pula yang menambahkan bahwa tradisi dalam PAN untuk menjadi Ketua Umum hanya untuk satu periode saja (http://www.konfrontasi.com) diakses tanggal 18 agustus 2016).

Sementara menurut pendukung Hatta Rajasa, beliau masih pantas memimpin PAN karena pada masa kepemimpinannya berhasil meningkatkan dukungan perolehan suara PAN dari 6,2 juta suara pada pemilu 2009 menjadi 9,5 juta suara pada pemilu 2014. Di bawah kepemimpinan Hatta Rajasa, PAN tampil menjadi kekuatan politik yang diperhitungkan dan disegani kawan maupun lawan. Selain itu, Hatta Rajasa dianggap dapat menjalankan partai secara total karena setelah setelah mundur dari menko (perekonomian) masa pemerintahan SBY, Hatta Rajasa total aktivitasnya di Partai dan komunikasi politik dengan daerah-daerah cair. (http://www.konfrontasi.com) diakses 18 agustus 2016).

Beberapa sumber mengatakan bahwa memang terjadi perbedaan pendapat diantara pendukung Hatta dengan pendukung Zulkifli. Perbedaan tersebut disebabkan karena ada sebagian kader yang menilai baik kinerja Hatta Rajasa dan masih menginginkan beliau untuk memimpin PAN. Kalaupun karena tradisi dalam PAN bahwa Ketua Umum PAN hanya menjabat satu periode, banyak kader PAN berharap visi dan misi yang diambil Zulkifli Hasan diharapkan sesuai dengan tujuan partai. Adanya perbedaan pandangan dalam kongres IV PAN dianggap bukan sebagai konflik tetapi sebagai salah satu dinamika internal yang pasti memunculkan berbeda pandangan antara kedua kubu PAN yang mengusung calon ketua umumnya masing-masing. Perbedaan pandangan antara kubu calon Ketua Umum PAN mungkin dapat berpengaruh pada institusi internal PAN dan bisa menyebabkan konflik berkepanjangan dalam internal PAN. Namun dalam kongres tersebut adanya konflik antara pendukung bisa diselesaikan dengan damai pasca terpilihnya Ketua Umum PAN tanpa harus terjadinya konflik yang berkepanjangan seperti terjadinya dualisme kepemimpinan partai seperti terjadi dalam beberapa partai politik lain (hasil wawancara informal dengan salah satu kader DPW PAN Jawa Barat di Kantor DPW PAN Jawa Barat, 5 Juni 2016).

Adanya konflik internal dalam kongres PAN ke IV tersebut merupakan salah satu pembelajaran politik, yang bisa diterapkan di beberapa partai politik. Konflik internal dalam suatu partai politik lumrah terjadi dalam intitusi politik, apalagi dalam konteks memperebutkan kekuasaan atau kepemimpinan dalam suatu partai. Namun adanya konflik internal tidaklah menyebabkan konflik yang berkepanjangan sampai terjadinya dualisme kepemimpinan suatu partai atau hengkangnya calon ketua umum yang kalah dalam kompetisi politik tersebut dengan mendirikan suatu partai politik yang baru.

Dalam konteks dinamika internal PAN, terjadinya konflik internal antara dua kubu pendukung calon Ketua Umum hanya terjadi saat pelaksanaan Kongres PAN tersebut, namun setelah kongres PAN tersebut selesai dan sudah terpilih Ketua Umum, kondisi internal PAN normal kembali, tidak ada perbedaan dan tetap berjalan seperti biasa (http://www.harianaceh. co.id 2015); diakses 20Agustus 2016).

Hal tersebut senada dengan apa yang disampaikan oleh Eddy Soeparno sebagai Sekretaris Jendral PAN dalam kepemimpinan Zulkifli Hasan bahwa "Ketika Kongres PAN ke IV di Bali berakhir pada tanggal 2 Maret 2015, para kader partai melebur kembali menjadi satu kesatuan yang solid sebagai kader PAN (dan bukan kubu HR ataupun ZH). Dalam kepengurusan DPP PAN masa bakti 2015 - 2020, banyak diantara anggota timses HR duduk sebagai petinggi partai, seperti Jon Erizal, Reza Rajasa dan A. Hafiz Tohir". (http:// beritakabar.com 2015) diakses 20 Agustus 2016)

Di sisi lain lain, pasca terpilihnya Zulkifli Hasan sebagai pemenang dalam pemilihan Ketua Umum PAN dalam kongres PAN ke IV tersebut memunculkan dinamika internal PAN yang baru. Dinamika yang terjadi dalam internal partai tersebut telah mempengaruhi strategi politik yang diterapkan oleh PAN sejak akhir 2015 lalu dengan tujuan untuk meningkatkan perolehan suara pada pemilu 2019 nanti. 
Perubahan srategi politik yang dilakukan PAN pasca Kongres IV tahun 2015 dapat dilihat antara lain dalam beberapa aspek, yaitu dalam komunikasi politik yang dilakukan partai secara internal dan eksternal, dalam tatacara pengkaderan hingga dalam proses permusyawaratan dalam melakukan pemilihan ketua di dewan pimpinan wilayah maupun daerah, dalam penentuan kepala daerah dan keputusan strategis politik daerah, serta dalam menjalankan aktivitas dan langkahlangkah partai.

Perubahan dalam komunikasi politik yang dilakukan PAN terjadi pada saat PAN menyatakan bahwa mereka akan mendukung pemerintah. Sebagaimana diinformasikan melalui berbagai media juga menurut narasumber dari DPW PAN Jawa Barat, kepemimpinan Zulkifli Hasan menggunakan taktik "politik tanpa dadu" dengan memutuskan untuk mendukung pemerintah. Meskipun dapat dikatakan bahwa bergabungnya PAN untuk mendukung pemerintah yang diisi oleh Koalisi Indonesia Hebat (KIH) secara tidka langsung membuat PAN bergabung dalam ke dalam $\mathrm{KIH}$, namun PAN sendiri tidak ingin menyatakan bahwa mereka keluar dari Koalisi Merah Putih (KMP) yang mereka bentuk saat Pilpres tahun 2014 lalu. Perubahan strategi politik PAN tersebut memunculkan berbagai tanggapan yang menyatakan bahwa langkah yang diambil PAN untuk mendukung pemerintah ini adalah strategi yang tepat dan akan menghasilkan kestabilan politik di Indonesia. Dalam hal ini PAN dinilai memainkan suatu langkah strategis dimana PAN berperan penting sebagai jembatan komunikasi politik antara dua kubu yang berkoalisi, yang mungkin selama ini tidak ada yang menjembataninya. Komunikasi politik dan koordinasi yang sebelumnya kurang dilakukan di antara kedua kubu, bila ada yang menjembatani dipandang akan sangat berdampak positif pada kinerja yang baik antara eksekutif dan legislatif dalam menentukan kebijakan yang baik, tepat dan cepat. Dengan memainkan peran sebagai "jembatan komunikasi politik" antar dua kubu, peran PAN berubah menjadi sangat penting, dari yang hanya sekedar anggota dari KMP menjadi "public relation atau broker" kedua kubu. PAN dapat memainkan fungsi sebagai broker dalam hubungan dua kubu, karena dianggap paling bisa masuk dan berkomunikasi di antara $\mathrm{KIH}$ dan KMP, dimana PAN bersikap "netral".
Dengan melakukan strategi politik tersebut diharapkan PAN bisa semakin eksis dalam panggung perpolitikan Indonesia. Jika peran PAN tersebut dijalankan dengan baik, maka PAN akan mendapatkan keuntungan jangka panjang yaitu sebagai partai yang mendominasi kursi parlemen dengan memenangkan pemilu bahkan dapat memunculkan tokoh yang akan duduk dalam pemimpin di eksekutif (http:// www.kompasiana.com 2016) diakses 18 Agustus 2016).

Aspek lain dari perubahan strategi politik PAN adalah dengan menciptakan suatu program partai yang bertajuk "Sabang Merauke (Safari Kebangsaan Merajut Kebhinekaan)". Walaupun program ini juga mirip dengan program "Safari Ramadhan" yang dilakukan saat kepemimpinan Hatta Rajasa, namun program yang baru diciptakan saat kepemimpinan Zulkifli Hasan ini memiliki perbedaan, yaitu dalam program Sabang Merauke dilakukan kunjungan-kunjungan ke seluruh wilayah dari Sabang hingga Merauke. Pada bulan Ramadhan tahun ini, kunjungan tersebut hanya difokuskan di wilayah Jawa Barat. Program Sabang Merauke disambut baik oleh para DPW dan DPD hingga para fraksi DPRD yang ada, yang kunjungannya diikuti oleh pimpinan DPW, DPD dan Fraksi PAN di DPRD ke wilayah yang telah ditentukan. Walupun program ini dilakukan dengan tujuan untuk menjaga keutuhan NKRI dan mempertahankan budaya yang ada di dalamnya, namun dapatlah dinilai bahkan program ini sebagai sarana komuniaksi politik yang dilakukan PAN dengan kader-kader dan anggotanya sampai ke daerah atau wilayah di Indonesia. Dengan demikian program ini juga merupakan salah satu aspek dari strategi politik PAN bagi internal PAN sendiri agar semakin solid, terbangunnya komunikasi politik serta terciptanya kaderisasi partai yang tidak hanya dilakukan di Pusat tetapi juga sampai ke daerah atau wilayah.

Perubahan strategi politik PAN lainnya adalah perubahan tata cara pengkaderan, dengan adanya sistem pengkaderan yang baru, yaitu Sekolah Politik Kerakyatan (SPK). SPK ini diterapkan kepada kader-kader muda dengan tujuan untuk menciptakan kaderkader muda yang berkualitas dan menjadi kader muda penerus PAN yang berkompeten. Proses pengkaderan yang muncul ini berbeda dengan proses pengkaderan yang diterapkan 
oleh kepemimpinan Hatta Rajasa yang lebih konsen dengan membentuk organisasi-organisasi otonom (Hasil wawancara dengan narasumber PAN DPW Jawa Barat di Kantor DPW PAN Jawa Barat, 5 Juni 2016).

Perubahan lainnya dalam strategi politik PAN terjadi dalam permusyawaratan untuk memilih Ketua Dewan Pimpinan Wilayah (DPW) maupun Dewan Pimpinan Daerah (DPD). Pada masa kemimpinan sebelumnya (Kepemimpinan Hatta Rajasa), baik proses pemilihan Ketua DPW maupun Ketua DPD dilakukan dengan cara one man one vote dalam bentuk musyawarah, namun saat ini mengalami perubahan yaitu proses pemilihan dilakukan dengan cara formatur, Meskipun dalam melakukan penentuan Ketua dengan cara formatur ini bisa terjadi atau menemui deadlock, maka akan dilakukan voting juga. Namun yang membedakan adalah pada saat sebelumnya untuk memilih ketua baik DPW maupun DPD langsung menggunakan sistem voting tanpa melalui musyawarah terlebih dahulu, sedangkan pada sistem yang sekarang ini lebih mengutamakan musyawarah dibandingkan voting.

StrategiPANlainnya pascaKongres IV 2015 adalah sebagai PAN lima tahun ke depan, harus dibuka sirkulasi demokrasinya. Pengurus DPD dan DPW diberi otonomi luas (desentralisasi politik) dalam mengambil sikap politik strategis, terutama berkaitan dengan penentuan kepala daerah dan kepu-tusan strategis politik daerah (http://www.kompasiana.com, 2016) diakses 20 agustus 2016).

Strategi politik PAN terkait masa depan PAN juga dikemukakan oleh Sekretaris Jendral PAN Eddy Soeparno bahwa "Ada pepatah mengatakan, generasi tua berbicara tentang sejarah tapi generasi muda akan menentukan arah sejarah. Kami melihat bahwa anak muda akan menjadi salah elemen penting dalam pemenangan partai. Ini bisa dilihat bahwa pengguna internet di Indonesia tahun 2014 mencapai hampir 90 juta orang, yang mana sebagian besar di dominasi generasi muda (rentang usia 18-35 tahun). Dari gambaran ini, kami memang harus bisa aktif terlibat dalam komunitas komunitas dan masyarakat netizen. Tentu kami tidak bisa melakukan komunikasi 'hard sell', karena netizen ini memiliki karakteristik yang berbeda dengan masa akar rumput. Mereka lebih kritis tapi sekaligus obyektif dalam melihat permasalahan. Dari percakapan yang terjadi di social media, kita bisa memahami persoalan bangsa ini serta memetakan langkah langkah partai"'(http:/beritakabar.com, 2015) diakses 20 agustus 2016). Hal tersebut menunjukkan bahwa dalam menjalankan aktivitas dan langkah-langkah partai, PAN juga senantiasa memperhatikan berbagai persoalan, informasi dan pendapat dari komunitas maupun masya-rakat netizen dari media social yang beraneka ragam terkait persoalan bangsa, tidak hanya persoalan internal partai.

Dalam pandangan penulis, adanya perubahan dalam sistem pemilihan Ketua DPW dan DPD tersebut di satu sisi menunjukkan bahwa proses demokrasi di internal PAN djalankan dengan baik dengan memberikan kesempatan pada anggota atau pihak internal PAN di daerah membangun komunikasi politik di antara mereka dalam menentukan pemimpin di wilayah dan daerahnya dengan terlebih dulu mendengarkan aspirasi yang berkembang dari anggota/kader partai yang ada di dalamnya untuk menentukan dan memilih pemimpinnya yang di anggap paling tepat. Adanya system permusyawaratan ini juga menunjukkan adnya itikad yang baik untuk tetap menghidupkan demokrasi yang berasaskan kekeluargaan yang menjadi ciri khas demokrasi Indonesia berdasarkan nilai-nilai Pancasila. Di sisi lain, karena pemilihan ketua DPW dan DPD dilakukan dalam bentuk musyawarah (cara formatur) dan bila tidak menghasilkan suara mufakat dilakukan voting, dinilai beberapa pihak terjadi inefisiensi waktu, tenaga dan biaya.

Perubahan-perubahan strategi dalam beberapa aspek di atas adalah perubahan yang dipengaruhi oleh dinamika internal partai yang terjadi pasca kongres PAN ke IV tahun 2015. Adanya beberapa perubahan strategi politik tersebut tidak hanya berpengaruh bagi internal PAN tetapi juga berpengaruh bagi eksternal PAN, yang bertujuan untuk meningkatkan peran dan kinerja politik PAN dalam kancah politik nasional. Perubahan strategi politik tersebut diharapkan dapat menambah kepercayaan politik dari masyarakat serta meningkatkan elektabilitas PAN untuk pemilu yang akan datang. 


\section{SIMPULAN}

Adanya dinamika internal dalam Partai amanat Nasional saat kongres IV 2015 yang dalam prosesnya ditengarai sempat memunculkan konflik internal antara dua kubu calon ketua umum Partai, dapatlah dilihat sebagai salah satu pembelajaran politik dimana konflik yang terjadi pada saat perebutan kekuasaan di internal partai tersebut tidak berlanjut ke konflik yang berkepanjangan sampai terjadinya dualisme kepemimpinan partai tersebutatau hengkangnya calon ketua umum yang kalah dalam kompetisi politik tersebut dengan mendirikan suatu partai politik yang baru.

Adanya pergantian kepemimpinan partai yang baru dalam PAN juga memunculkan strategi politik PAN yang tidak hanya berpengaruh bagi internal PAN tetapi juga berpengaruh bagi eksternal PAN, yang bertujuan untuk meningkatkan peran dan kinerja politik PAN dalam kancah politik nasional. Perubahan strategi politik tersebut diharapkan dapat menambah kepercayaan politik dari masyarakat serta meningkatkan elektabilitas PAN untuk pemilu yang akan datang.

\section{DAFTAR PUSTAKA}

Arifin, Anwar. 2011. Komunikasi Politik. Yogyakarta: Graha Ilmu.

Budiardjo, Miriam. 2015. Dasar-dasar ilmu Politik (Edisi Revisi). Jakarta: PT Gramedia Pustaka Utama.

Haris, Syamsuddin. 2014. Partai, Pemilu dan Parlemen Era Reformasi. Jakarta: Yayasan Pustaka Obor Indonesia.

Mas'oed, Mochtar dan Clin McAndrews. 2008. Perbandingan Sistem Politik. Yogyakarta: Gadjah Mada University Press.

Peter Schroder. 2008. Strategi Politik (Poltische Strategien) Edisi Revisi. Jerman:
Friedrich-Naumann-Stiftung fuer die Freiheit. Di akses dari https://www.scribd. com/doc/150085853/Peter-SchroederStrategi-Politik

Oxford. 2003. Oxford Learner's Pocket Dictionary, English: Oxford Dictionary Press.

Pemerintah Republik Indonesia. 2008. Undang-Undang No. 2 Tahun 2008 tentang Partai Politik.

Jatmiko, Brian Andry. 2010. Dinamika Politik Partai Golkar 1998-2004. Skripsi Universitas Sebelas Maret.

http://www.maribelajarbk.web.id/2015/04/ pengertian-dinamika-kelompokmenurut-html

http://news.detik.com/berita/2827195/ panasnya-persaingan-hatta-vs-zulkiflijelang-kongres-pan

http://www.konfrontasi.com/content/politik/ zulkifli-hasan-dianggap-pantas-jadiketum-pan

http://www.konfrontasi.com/content/ragam/ banyak-yang-sedih-bila-hatta-tak-lagimemimpin-pan

http://www.harianaceh.co.id/2015/03/15/ demi-dirikan-partai-baru-hatta-rajasabantah-akan-tinggalkan-pan/20

http://beritakabar.com/2015/03/30/ wawancara-khusus-dengan-sekjenpan-eddy-soeparno.html

http://www.kompasiana.com/lingga. immanuel/langkah-strategis-partaiamanat-nasional-pan

h t t p :// w w w . k o mpasian a.com/ perempuanmerah/tim-abs-hattarajasa-vs-tim-santun-zulkiflihasan_54f351b17455139e2b6c70e2 